\title{
State Interventionism in Agricultural Land Turnover in Poland
}

\author{
Agnieszka Stacherzak ${ }^{1}\left[\right.$, Maria Hełdak ${ }^{1, *(1)}$, Ladislav Hájek ${ }^{2}$ (D) and Katarzyna Przybyła ${ }^{1}$ (D) \\ 1 Department of Spatial Economy, Faculty of Environmental Engineering and Geodesy, \\ Wrocław University of Environmental and Life Sciences, ul. Grunwaldzka 55, 50-357 Wrocław, Poland; \\ agnieszka.stacherzak@upwr.edu.pl (A.S.); katarzyna.przybyla@upwr.edu.pl (K.P.) \\ 2 Economics Department, Faculty of Informatics and Management, University of Hradec Králové, \\ Rokitanského 62, 50003 Hradec Králové, Czech Republic; ladislav.hajek@uhk.cz \\ * Correspondence: maria.heldak@upwr.edu.pl
}

Received: 24 January 2019; Accepted: 4 March 2019; Published: 13 March 2019

\begin{abstract}
The study discusses the problem of land grabbing and state interventionism in agricultural land transactions in Poland, and presents the effects of active policy implemented by the state on limiting the flow of agricultural land. The research covers the period from the time of country's accession to the European Union, starting from 2004. Poland introduced restrictions on the purchase of agricultural land for fear of mass land grabbing, and has currently tightened the restrictions on agricultural land purchase by foreigners and by non-owners of a family farm. The analyses concern the number of permits issued for foreigners to turn over agricultural land in Poland, the area of property eventually purchased by foreigners, the right of pre-emption exercised by the National Support Centre for Agriculture (NSCA), and the number of transactions concluded in an open market and in the form of a tender. Based on the collected data and their in-depth analyses, the following phenomena were interpreted: an extensive impact of interventionism exercised by the Polish state on restricting the sale of agricultural land to foreigners is observed, and interventionism of the Polish state affects the suspension of functional changes in rural areas and agricultural land transition to non-agricultural purposes. The research shows that the majority of property turnover by foreigners in Poland required permits issued by the Minister of the Interior Affairs and Administration. Moreover, priority is given to owners of family farms, which results in a reduction of the total number of transactions concerning agricultural land in Poland after introducing changes in legal transactions of agricultural land in 2016.
\end{abstract}

Keywords: land grabbing; state interventionism; interventionism in agriculture; agricultural land purchase; loss of prime agricultural land; agricultural policy; European Union

\section{Introduction}

The globally observed mass purchase of land, and predominantly land grabbing, has been the manifestation of unfavourable processes occurring in recent years. The Official Journal of the European Union 2015/C 242/03 of 23 July 2015 refers to the problems related to mass purchase of agricultural land, its concentration in the hands of large investors outside the agricultural sector, and large agribusiness, which are perceived as a threat to family farming worldwide. Estimates by the International Food Policy Research Institute (IFPRI) suggest that roughly 20 million hectares exchanged hands in the form of land grabs between 2005 and 2009 [1-5].

Land grabbing has become a catch-all phrase to refer to the current explosion of (trans)national commercial land transactions mainly revolving around the production and export of food, animal feed, biofuels, timber, and minerals [5]. This definition was also adopted in this work. 
As early as the 1980s, Pasour [6] wrote that the National Agricultural Lands Study (NALS) was just one among many recent works expressing concern about the loss of prime agricultural land, which was then confirmed by the Council on Agricultural Science and Technology (CAST).

Land grabs have taken place largely in places where buyers could exploit corrupt or indebted governments with little ability to regulate the transaction or prevent buyers from targeting the poorest rural communities, expelling people with non-traditional land titles from their land [7]. The problem of land grabbing has been discussed by many authors with reference to different regions of the world (concerns about the purchase of agricultural land in the countries formed after the collapse of the Soviet Union were expressed by, for example, Visser and Spoor [8] in Latin America; Borras et al. [2] in Southeast Asia; Borras and Franco [5]; Schoenberger et al. [9]; Colchester and Chao [10]; Manahan [11] and many other authors).

According to Schoenberger et al. [9], land grab studies have had a strong regional component from the beginning, with regions such as 'sub-Saharan Africa,' 'Latin America,' and 'Southeast Asia' featuring prominently in efforts to sketch the field's contours. Furthermore, in Central Europe this phenomenon is extensively diversified in particular countries, as there is no common agricultural policy in this domain. In the European Union countries, each member state develops regulations of agricultural land sale individually, and in some countries it is not a major problem. However, in some countries (including Poland), strict rules are maintained for potential buyers, for fear of mass buy out of land after easing the regulations restricting land purchases by foreigners.

Agricultural policy represents one of the methods of state intervention in market mechanisms, which is practically observed in various forms in Poland and all over the world. Interventionism in Polish agriculture, including the structure of agricultural land ownership, the formation of field layout, or limiting the flow of land, has a long history. Nowadays, it results more from the need to counteract undesirable processes related to excessive concentration and land use for non-agricultural purposes [12,13].

Davis et al. [14] write about the negative effects of transactions involving agricultural land. In a study of the 28 analysed countries most affected by transactions since 2000, they reported that, up to now, more than 12.1 million people have been directly affected by the immediate economic consequences of land purchase (the loss of income is particularly severe for households in African countries-Gabon, Liberia, Mozambique, Sierra Leone, and Southern Sudan/Sudan-Papua New Guinea, and Malaysia).

These concerns encouraged subsequent Polish governments to tighten up agricultural policy and interventionism regarding the purchase of agricultural land by foreigners. This was achieved by introducing the right of pre-emption, the implementation of a sales blockade of agricultural land owned by the State Treasury, only last year, and preferences for purchasing agricultural land by certain groups of citizens. Instead of considering opportunities to preserve farmland or to integrate new production functions into urban environments, agricultural landscapes are often considered by land use planners as areas for future development [15]. This deepens the problem of agricultural land transition to non-agricultural purposes in Poland, contributes to ongoing functional changes, and facilitates land property turnover previously classified as agricultural (with the absence of comparable legal restrictions for market turnover regarding non-agricultural land). The policy of local authorities results in functional changes, primarily in suburban city zones, the problem of which was raised by the co-authors of Reference [16].

The market economy began to impose new rules of action on farmers and agrifood sector companies, and, as a result, on economic categories such as competition, efficiency, and profit [17].

Similar concerns occur in Slovakia, Poland's neighbour. Slovakia is also afraid of foreigners buying out their land. According to Drabik and Rajčániová [18], Slovak farmers have feared the increase in demand for agricultural land since the land market was opened in May 2014. Although there are no official statistics how much agricultural land was purchased by foreigners before May 2014, some estimate it could be as much as 100,000 hectares (out of 1.9 million). 
In the recent period, an increased interest of foreign citizens, companies, and other agents in buying land in Romania has been observed. The sale and long rental of agricultural land has attracted massive attention socially, politically, and from local communities [19]. According to Constantin, in Europe, land grabbing occurs mostly in the Eastern and Central countries, particularly in Hungary and Romania, because they have some of the best agricultural land, with extremely fertile soil and water sources for irrigation in the Danube plain [20].

An extensive impact of the interventionism exercised by the Polish state in restricting the sale of agricultural land to foreigners has been observed. It is the manifestation of uncontrolled land takeover by the citizens of foreign countries, also perceived as a threat to state security. Restricting the sale of land to this group of buyers dates back to the period when Poland regained its independence in 1918, and restrictions were enacted for the first time in the Act of 24 March 1920 on the purchase of real property by foreigners [21]. This Act, in its amended form, has remained in force until today. The impact of legislation on the area of sold land, and the significant share of transactions for which the Minister of the Interior Affairs and Administration permit was granted, is now apparent.

The objective of the conducted research is to discuss the land grabbing problem and interventionism of Polish state in the sale of agricultural land, and to present the effects of active policy carried out by the state on limiting the flow of agricultural land. The size of property purchased by foreigners and the general tendencies of the occurring phenomena were specified in the study, as well as the volume of exercised pre-emption rights by the National Support Centre for Agriculture ("intercepting" agricultural land at the stage of purchase-sale transactions for the benefit of the State Treasury). The National Support Centre for Agriculture (NSCA) was established on the 1 September 2017, pursuant to the Act of the 10 February 2017 (Journal of Laws of 2017, item 623) [22]. Two agricultural agencies ceased to exist on that date: the Agricultural Market Agency and the Agricultural Property Agency.

\section{Materials and Methods}

The present research refers to recently introduced changes in legal provisions regarding the restrictions in terms of agricultural land sale. The authors also refer to changes in regulations introduced in this area by other Central and Eastern European countries, and the position presented by the European Union. The problem is of great importance, and of an international character which has recently been widely debated. It is a novelty to compare the actual interest in the sale of land by foreigners. The research covers the period from the time of the respective countries' accession into the European Union structures, i.e., since 2004. The analysis also covers the number of permits issued for foreigners to purchase agricultural land in Poland, and the area of property eventually purchased by foreigners. The scope of the conducted analysis also includes intervention activities carried out by the Agricultural Property Agency (APA—nowadays NSCA), consisting of exercising the pre-emption right of agricultural land and the sale of land from the State Treasury Agricultural Property (STAP). These activities are presented against the background of the agricultural land market in Poland.

Land change science is embedded in sustainability research, which strives to produce scientific knowledge for improving policies and decision-making with regard to sustainability goals [23-27].

The source materials used in the study were retrieved from the European Statistical Office (Eurostat) and the Central Statistical Office of Poland (GUS) database, the data published by the Ministry of Foreign Affairs and by the Agency for Agricultural Property of the State Treasury (NSCA) in the report on the activities of the Agricultural Property Agency within the framework of the State Treasury Agricultural Property [28-30].

The research material was collected by the national information units of the statistical services and by the European Commission. The analysis was carried out using the comparative method, in order to compare the results obtained in individual years. It was done to establish certain relationships, such as identity, similarity or difference between the characteristics, and facts. The research results illustrate further trends in the number and structure of permits issued for the purchase of agricultural land by 
foreigners, or the number of the actual agricultural land purchase and the number of pre-emptive rights exercised at the background of agricultural property transactions.

The method used in the study was as follows:

- identification of the research subject and selection of the study area;

- $\quad$ analysis of the scientific literature;

- collecting statistical information and developing the database covering: the number of permits issued for the purchase of land properties for foreigners in Poland, the number of agricultural and forestry property purchase transactions concluded by foreigners in Poland, agricultural land transactions, pre-emption rights (land acquisition by the State Treasury);

- analysis of the scale of agricultural land purchase by foreigners in Poland in the years 2004-2016,

- analysis of the scale of agricultural land turnover in Poland and the scale of pre-emption right execution (land acquisition by the State) in the years 2004-2016;

- conclusions.

The following research hypotheses are put forward in the article:

Hypothesis 1. Land grabbing is a major threat in Poland due to the relatively high interest in the purchase of agricultural land by foreigners;

Hypothesis 2. The interventionism of Polish state affects the suspension of functional changes in rural areas and agricultural land transition to non-agricultural purposes.

\section{Results and Discussion}

\subsection{Restrictions on the Purchase of Agricultural Land by Foreigners}

The purchase of ownership right or perpetual usufruct of a real property by a foreigner and the purchase or acquisition of stocks or shares by a foreigner in commercial companies based in Poland requires a permit to be issued by the Minister of the Interior Affairs and Administration. In order to obtain such permit, a foreigner must apply for its issuance. The application has to be prepared in accordance with the information contained in:

- $\quad$ The Act of 24 March 1920 on the acquisition of real property by foreigners (Journal of Laws of 2014, item 1380) [21];

- $\quad$ The Regulation of the Minister of the Interior Affairs and Administration of 20 June 2012 on detailed information and types of documents required to be presented by a foreigner applying for a permit to purchase real property (Journal of Laws of 2012, item 729) [31]. Restrictions on the purchase of land by foreigners have a long history in Poland; the Act is one of the oldest in force in the country.

In the year of Poland's accession to the structures of the European Union (2004), almost two thirds of farmers (65\%) declared that they would not sell their land to foreigners. Poland's accession to the EU entailed the abolition of requirements to obtain permits for the purchase of stocks and shares in companies holding land properties for citizens and entrepreneurs from the European Economic Area (EEA). In fact, the area of agricultural real property had already significantly decreased in 2005 against the previous year, for the purchase of which (under this type of transaction) permits were issued. This means that, primarily, EEA-based capital was interested in acquiring stocks and shares in companies holding agricultural land in Poland. The number of permits issued to foreigners for the purchase of agricultural land is presented below (Figure 1). 


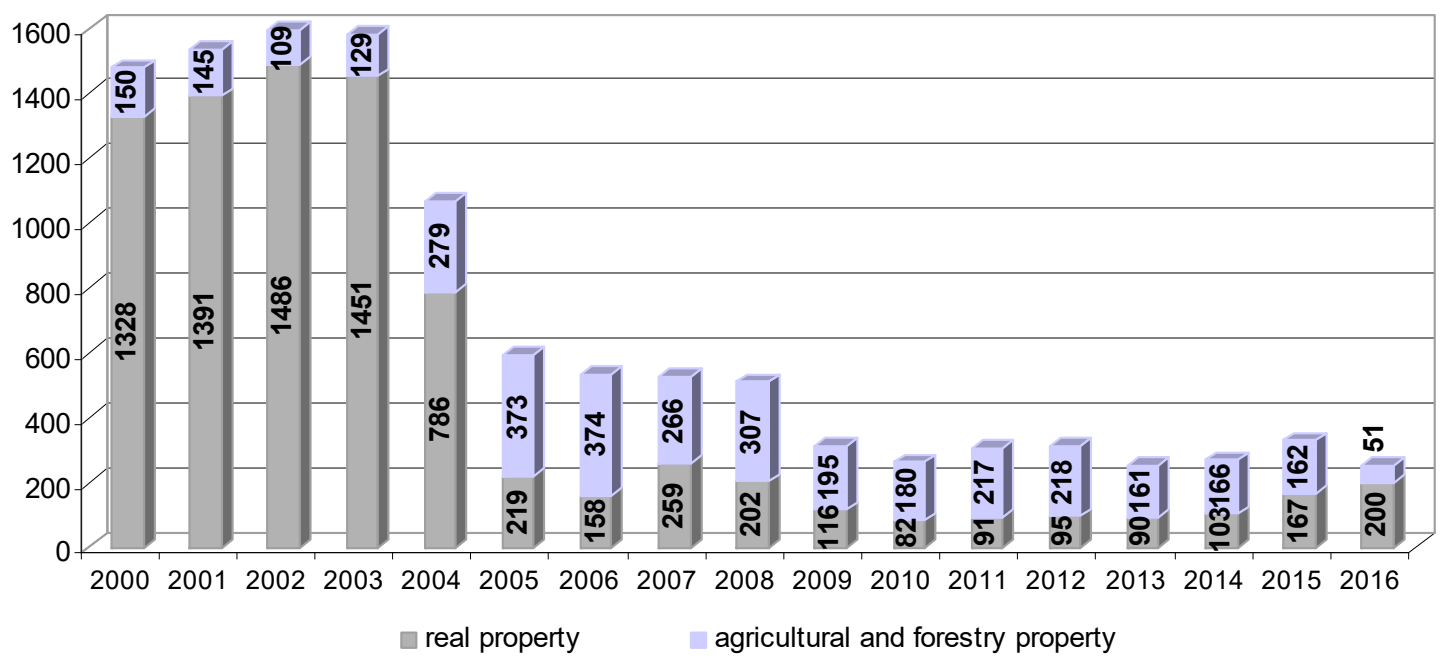

Figure 1. Total number of permits issued to foreigners for the purchase of real property and agricultural and forestry property. Source: authors' compilation.

In the years 2005-2016, on average, about 220 permits were annually issued for the purchase of land by foreigners. In Poland, invariably, the main real property buyers (in terms of the number of contracts concluded) are German, Dutch, and Danish investors. The area of agricultural land purchased by foreigners on the basis of granted permits and without the required permits is presented below (Figure 2).

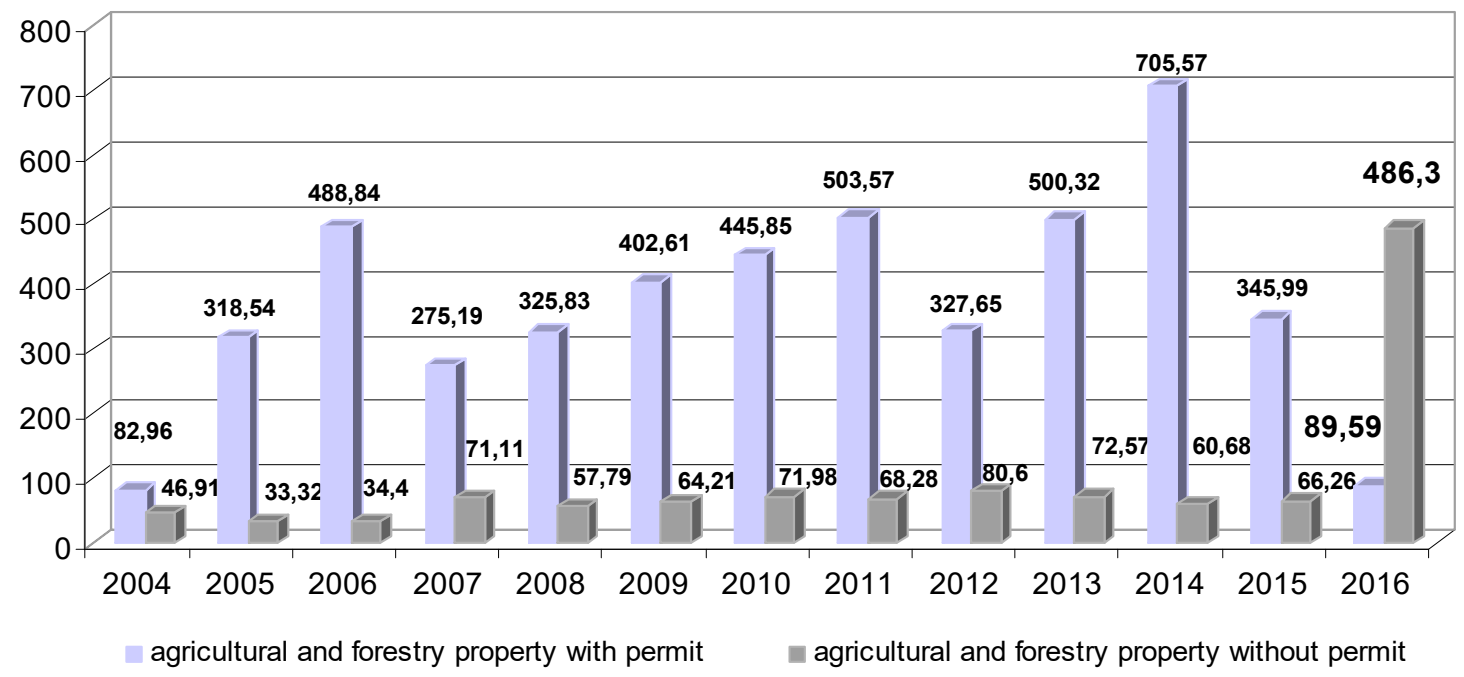

Figure 2. The number of transactions concluded by foreigners for the purchase of agricultural and forestry property on the basis of a permit and without the required permit. Source: authors' compilation.

It was found that in the period 2004-2015, the transactions for the purchase of agricultural land in Poland were concluded mainly after issuing the required permit by the Minister of Internal Affairs and Administration. Following the changes in legislation, in 2016 this ratio has been reversed and more transactions concluded without the permit granted by the state authorities were recorded.

The recipient countries' governments play a key role in facilitating land investments through favourable land and trade policies, but also by establishing — and benefitting from—legal pluralism to ensure 'formal' land rights for investors [23].

Due to the ban period on the sale of agricultural land to foreigners coming to an end, the Ministry of Agriculture has taken steps to change agricultural property sale after 2016. First, the Act of 24 March 
1920 on the purchase of real property by foreigners was addressed (Journal of Laws of 2004, No. 167, item 1758, as amended) [21]. Previously, a permit was required for the period of 12 years from the date of the Republic of Poland accession to the European Union, i.e., until 1 May 2016. At the end of this period, i.e., after 1 May 2016, the requirement to obtain such a permit for the purchase of agricultural property continued to apply to entities originating outside the European Economic Area (the EU Member States, Iceland, Liechtenstein, and Norway) and the Swiss Confederation.

After the end of the transition period (after 1 May 2016), the turnover of agricultural property (in relation to entities from the European Economic Area and the Swiss Confederation) became subject to restrictions pursuant to the Act of 11 April 2003 on the formation of agricultural systems, and the Act of 19 October 1991 on the management of agricultural property of the State Treasury, as analysed below.

\subsection{Sale of Agricultural Land in Poland}

Currently, state interventionism in terms of agricultural land turnover discontinuation in Poland is relatively far-reaching, and, recently, the tools restricting agricultural land turnover have been additionally strengthened. It refers to the reinforcement of agricultural land protection in Poland before it is bought out by natives and foreigners who do not guarantee a socially acceptable use of the acquired land for agricultural purposes (Act of 14 April 2016 on sale suspension of the State Treasury Agricultural Property and the change of some laws (Journal of Laws of 2016, item 585)-enforced on 30 April 2016) [32]. The following changes can be listed among the most important:

- the possibility of purchasing agricultural land by individual farmers only;

- enforcing numerous obligations on the purchase of agricultural land-e.g., the obligation of running a farm personally for a period of 10 years by the purchasing party;

- $\quad$ enforcing the procedure of granting consent by the President of the Agricultural Property Agency (NSCA) for the purchase of agricultural real property in specific cases;

- extending the right of agricultural property purchase vested by the Agricultural Property Agency on, for example, administrative decisions, positive prescription, acquisition by way of execution;

- enforcing the right of pre-emption and redemption in relation to stocks and shares of companies that own agricultural property;

- turnover discontinuance of agricultural land owned by the State Treasury (previously, the sale was conducted in the form of a tender and a non-tender procedure).

As indicated by Hełdak et al. [33,34], after Poland's accession to the European Union, a significant increase in average transaction price per hectare was noticeable. Integration with the European Union stimulated higher activity on the real property market in Poland. In 2015, the average price of agricultural land increased almost six times compared to 2004.

Currently, in Poland, the sale of land owned by the State Treasury is performed in the form of a tender and a non-tender procedure. Area structure improvement, and especially providing conditions for the expansion of existing family farms, was encouraged by the restricted tender procedure, organized by the Agency, for individual farmers expanding their family farms. Since the beginning of this power enforcement (i.e., since mid-June 1999), restricted tenders for farmers were settled for the purchase of 222,100 hectares and for the lease of 261,400 hectares.

Land turnover involving the public sector primarily concerns the sale of land from APA resources (owned by the State Treasury) carried out in the form of a tender and a non-tender procedure (Table 1). 
Table 1. Agricultural land transactions according to the form of turnover in the years 2004-2016 by the number of transactions.

\begin{tabular}{cccccc}
\hline & & & \multicolumn{3}{c}{ Turnover Form (Percentage) } \\
\cline { 4 - 6 } No. & Year & Number of Plots & Free Market & $\begin{array}{c}\text { Sale without Tender } \\
\text { Procedure }\end{array}$ & $\begin{array}{c}\text { Sale under Tender } \\
\text { Procedure }\end{array}$ \\
\hline nnyyy & & & no data & no data & no data \\
2. & 2004 & 87,493 & no data & no data & no data \\
3. & 2005 & 80,858 & 84.8 & 4.7 & 10.5 \\
4. & 2006 & 84,939 & 85.9 & 4.0 & 10.1 \\
5. & 2008 & 104,289 & 85.7 & 4.2 & 10.1 \\
6. & 2009 & 84,763 & 86.1 & 4.8 & 9.2 \\
7. & 2010 & 95,160 & 85.6 & 3.8 & 10.6 \\
8. & 2011 & 104,191 & 87.7 & 3.7 & 8.6 \\
9. & 2012 & 109,455 & 85.8 & 4.3 & 8.0 \\
10. & 2013 & 155,411 & 86.5 & 4.6 & 8.4 \\
11. & 2014 & 161,548 & 87.2 & 4.4 & 7.7 \\
12. & 2015 & 199,105 & 88.4 & 3.9 & 3.8 \\
13. & 2016 & 100,571 & 93.5 & 2.7 & \\
\hline
\end{tabular}

Source: authors' compilation.

In Poland, in the years 2004-2016, the sale of agricultural land ranged from 80,000 to 199,000 plots annually. The number of agricultural land transactions increased in subsequent years, and more than doubled in 2015 compared to 2004. These numbers included free-market transactions in the form of tender and a non-tender procedures. Many real property agencies indicate that the number of customers interested in acquiring agricultural land has drastically declined. This probably results from the concerns related to the restrictions introduced by the Act on the suspension of sale of agricultural real property, in connection with the ban on the sale of agricultural land for 10 years from the date of purchase. A significant drop in the number of agricultural property transactions carried out in 2017 was noticeable, which was equal to $82.4 \%$ of the transactions concluded in 2016 [28]. The declining number of transactions is the result of changes in legal regulations introducing restrictions on the acquisition of agricultural land. It is difficult to find any other reasons for such behaviour of the agricultural property market. First of all, agricultural land cannot be purchased by a person who does not own an agricultural holding (the buyer has to be the owner of an individual "family" farm). In addition, the final decision is currently in the hands of the National Centre for Agricultural Support, which can exercise the right of pre-emption (take the place of the agricultural land purchasing entity). It discourages land owners from selling their land, as well as speculators searching for attractively located agricultural land with a large investment potential from purchasing it.

At present, attempts are being made to change the condition for obtaining approval of the National Centre for Agricultural Support to sell agricultural land to a person who is not a farmer that requires the owner to show that no individual farmer is interested in purchasing this particular property. It applies to all properties with an area of more than 0.3 ha. This introduces additional restrictions, and some risks to be taken by the buyer.

State interventionism is present in the agricultural land market in Poland, however, free-market sales still dominate. In 2015 , as many as $88.4 \%$ of transactions were concluded on the free market, and in previous years this share was equally high and reached a comparable level. At present (since 30 April 2016), the sale of real property or its part, included in the resources of the State Treasury Agricultural Property (NSCA) within the period of 5 years from the date of the Act enforcement, was legally discontinued, i.e., the share of tender transactions will be reduced further compared to the currently small share.

Land acquisition is commonly associated with a general revaluation of rural areas, providing private and public goods in a globalized and increasingly urbanized world [27].

Pursuant to the changes in legal regulations and the suspension of agricultural land market, the number of transactions in agricultural property showed a sharp decline $(49.5 \%$ fewer plots of 
agricultural land were sold in 2016 than 2015). Such transactions are presumed to occur primarily on the free market, because the percentage share of transactions concluded by the state authorities and local government dropped by several percentage points. The change in the regulations resulted in the stabilization of agricultural land prices in 2016. No rapid drop in transaction prices was recorded, only a decline in the number of concluded transactions. Having analysed the transaction prices of agricultural land over the last dozen or so years, it can be concluded that the average price of agricultural land in Poland has been systematically growing. This is the effect of Poland joining the EU, higher profitability of agricultural production, and introducing direct payments. In 2004 (Poland's accession to the EU), the average price of 1 hectare of agricultural land amounted to 6600 PLN, whereas in the second quarter of 2016, approx. 39,500 thousand PLN [28].

The basic form of state agricultural land management is supposed to be a long-term lease, providing the ownership control over its management method. The land will be distributed, following tenders limited to leases for people intending to expand or establish a family farm. The duration of newly concluded lease contracts will, as a rule, cover a period of 10 years. The right of pre-emption, along with other restrictions in agricultural land turnover, contributed to the stabilization of agricultural land prices in the period after the restrictions came into force in April 2016. In the subsequent year, the average sale prices of agricultural land in private trading in Poland increased by over $8 \%$, similarly to rental fees. Between 2015 and 2016, the price of agricultural land went up by $10 \%$, and rental fees by $1.4 \%$. Between the years 2014 and 2015, the discussed prices increased by $13 \%$ and rental fees went slightly down [33,34]. Along with limiting the group of potential agricultural land buyers, the growth rate of agricultural land prices decreased, whereas rental fees increased in private trading.

\subsection{The Right of Pre-Emption of Agricultural Land for the Benefit of the State Treasury}

The Agricultural Property Agency (NSCA), which exercises this right in the form of pre-emption and redemption, controls agricultural land turnover in Poland. The right of pre-emption applies to the situations identified in the Act of 11 April 2003 on the formation of agricultural systems, and consists of the right to enter the position of the buyer and purchase agricultural property for the price and under the conditions previously specified by the seller and the buyer $[35,36]$.

This right was granted to the Agricultural Property Agency on 16 July 2003. The area of agricultural land included in the resources of the State Treasury Agricultural Property by 31 December 2015 amounted to the total of 4,739,396 ha. At that time, the APA exercised the right of pre-emption in 629 cases, of which 10 cases were in 2015 and 14 cases in 2016 (Table 2).

Table 2. The area of agricultural land taken over by the Agricultural Property Agency (APA, NSCA).

\begin{tabular}{|c|c|c|c|c|c|}
\hline \multirow[b]{2}{*}{ No. } & \multirow[b]{2}{*}{ Year } & \multicolumn{2}{|c|}{ Area of Taken over Agricultural Land(ha) } & \multicolumn{2}{|c|}{ Number of Sales Contracts of Agricultural Property } \\
\hline & & $\begin{array}{c}\text { Taken over } \\
\text { Total }\end{array}$ & $\begin{array}{l}\text { Including Based on the } \\
\text { Right of Pre-Emption }\end{array}$ & $\begin{array}{c}\text { Total Submitted to the } \\
\text { APA (NSCA) }\end{array}$ & $\begin{array}{l}\text { Including the Exercised } \\
\text { Right of Pre-Emption }\end{array}$ \\
\hline 1. & 2004 & 2834 & 1356 & no data & no data \\
\hline 2. & 2005 & 3013 & 1991 & no data & no data \\
\hline 3. & 2006 & 2584 & 1665 & no data & no data \\
\hline 4. & 2007 & 5406 & 3700 & 118,000 & 162 \\
\hline 5. & 2008 & 1298 & 847 & 103,000 & 70 \\
\hline 6. & 2009 & 1297 & 650 & 81,300 & 18 \\
\hline 7. & 2010 & 919 & 453 & 38,000 & 10 \\
\hline 8. & 2011 & 425 & 61 & 2500 & 5 \\
\hline 9. & 2012 & 519 & 186 & 2700 & 7 \\
\hline 10. & 2013 & 517 & 450 & 2600 & 14 \\
\hline 11. & 2014 & 189 & 189 & 2500 & 9 \\
\hline 12. & 2015 & 1291 & 1291 & 2500 & 10 \\
\hline 13 & 2016 & 1760 & 1194 & 2700 & 14 \\
\hline 14. & Total: & 22,052 & 14,033 & 355,800 & 319 \\
\hline
\end{tabular}

Source: authors' compilation based on [Reports on the activities, 2003-2017]. 
Currently, the Act on the formation of agricultural systems remains the basic entitlement for agricultural property purchase into the resources of the State Treasury Agricultural Property. It opens an opportunity to use private land to support positive structural changes (the right of pre-emption, redemption) in agriculture.

After the changes in legislation, since 30 April 2016, the statutory right of pre-emption was retained, providing that, in the absence of the person eligible for the right of pre-emption, referred to in paragraph 1, or his/her failure to exercise this right, the right of pre-emption was vested, under the Act, to the Agency acting for the benefit of the State Treasury. After the amendment of law, the right of pre-emption of a farm belongs to the lessee.

Overpricing in a third-party sales agreement, to prevent APA (NSCA) from exercising the right of pre-emption, is ineffective. This standpoint was taken by the Supreme Court in Poland in its decision of 25 December 2008, II CNP 70/08, LEX No. 484703, stating [37] that all provisions of the sale contract entered into by the obligor with the third party in order to defeat the pre-emption right are ineffective (Art. $600 \S 1$ Civil Code) against the entitled person. This means that the state services (APA), if they consider it necessary to take over a property from the transaction already made, may do so at a price other than the contract parties-usually lower. However, the situations in which the right of pre-emption is exercised are rare-since 2007 and 2008, the number of agricultural land takeovers by the state has fallen rapidly. This resulted from the change in regulations after 2008, which did not allow the right of pre-emption to be exercised for agricultural property less than 5.00 ha; now (after 30 April 2016), the area of 0.3 ha is the limit. Thus, we face further tightening of the provisions restricting the free flow of agricultural land.

Under the new legal conditions, the National Support Centre for Agriculture (NSCA) also issues administrative decisions for the purchase of agricultural property on the private market. Based on the report, in the period 30.04.2016-31.12.2016, NSCA received 6954 applications regarding the transfer of agricultural property ownership, following which 4087 administrative decisions were issued in relation to the purchase of agricultural land, covering a total area of 11,542 ha, including [29]:

- $\quad 3730$ positive decisions (91\% of all decisions) regarding the total area of 10,116 ha, based on which the sale of land is possible on an open market;

- $\quad 52$ negative decisions ( $1 \%$ of all decisions) regarding a total area of 565 ha, based on which the sale of land was suspended;

- $\quad 305$ discontinuance decisions ( $8 \%$ of all decisions) regarding a total area of 861 ha-the application was unfounded.

It is planned, however, to strengthen the state intervention in the purchase of agricultural land through exercising the right of pre-emption. According to Gajewska and Iwaszkiewicz [38], in the financial plan of the Resource, $30 \%$ of expenditure is allocated to the implementation of tasks related to exercising the right of pre-emption and buy-out.

Since 1 January 2018, a new restriction on the sale of property has come into force in the Polish legal system [39]. The legislator introduced the pre-emptive right for the State Treasury into the new Water Law in the case of selling land under inland standing waters. The right of pre-emption is exercised by the County Governor after consulting the Minister responsible for water management (currently the Minister of the Environment). The sale of such land can be carried out if the County Governor does not execute the right of pre-emption, which applies to the entire property. The right of pre-emption can be exercised within one month from the date of a notification receipt by the County Governor about the content of the sales agreement, whereas the Notary Public preparing the sales agreement is obliged to notify the County Governor about the content of such an agreement. To date, there is no information on exercising the right of pre-emption vested to this title.

The newly introduced Polish regulations are more restrictive than German and French ones. Currently, the European Union authorities are in dispute with Bulgaria, Lithuania, Latvia, Hungary, and Slovakia, which have all earlier implemented similar regulations to Poland. The constraints 
imposed by these countries, according to the EU representatives, violate the principle of free movement of capital and discriminate against EU citizens in terms of the country of origin.

The regulations refer to, for example:

- $\quad$ restrictions imposed on owners and their qualifications (preferred natural persons presenting the respective education, practice in running agricultural production-Slovakia, Hungary);

- $\quad$ the possibility of buying agricultural land only by persons permanently residing in a given country (Slovakia-min. 10 years, Bulgaria-min. 5 years, Hungary-min. 3 years);

- $\quad$ obligation of agricultural land use in the subsequent years (Hungary min. 5 years);

- $\quad$ pre-emptive right of the state land for shareholders and co-owners of farms adjacent to the field intended for sale (Lithuania, Romania, Slovakia);

- $\quad$ limiting the maximum size of a farm to 300 ha of owned land (Lithuania, Hungary).

\section{Conclusions}

The conducted analyses allowed us to put forward the conclusions presented below:

Based on the conducted research, it is difficult to confirm Hypothesis 1, stating that land grabbing is a major threat in Poland due to the relatively high interest in the purchase of agricultural land by foreigners. The limitation of agricultural land sales, and the permits required for the purchase of land, reduce the problem of land grabbing. The abolition of regulations would certainly encourage buyers from the Western European countries to purchase agricultural land in Poland.

It is also difficult to identify the phenomenon observed in Europe with those occurring in Asia or Africa. There are, however, various scholars who use "land grabbing" as a synonym for investments taking place without thoroughly reflecting on what it means, for example in the European context [40-43].

Apart from land grabbing by people with foreign capital, the Polish state also runs the policy of interventionism towards its citizens. The essence of the agricultural system formation policy in Poland is to use the right of pre-emption and redemption by the state to purchase land in private circulation, and then sell it to individual farmers on a preferential basis. It therefore represents the policy aimed at influencing the private market in order to stimulate the flow of land into family farms. This is confirmed by Hypothesis 2, assuming that interventionism of the Polish state affects the suspension of functional changes in rural areas and agricultural land transition to non-agricultural purposes.

The changes in regulations to restrict the purchase of agricultural land are assessed negatively by developers who often invest in agricultural land, and also by natural persons planning to sell land to non-farmers. It limits the development of agricultural activity and results in agricultural land reclassification for non-agricultural purposes. Paradoxically, this law restricts the speculation of agricultural land in Poland. The purchase of agricultural land for immediate profit, consisting of its purchase at a lower price, often from unaware farmers, land reclassification for investment purposes, and sales with profit are blocked.

Poland is one of the few countries with such extensive protection of agricultural land. The rules on the formation of agricultural systems and on the purchase of real property by foreigners have as many supporters as opponents. Both domestic and international accumulation of land is dealt with in the domestic context of agricultural development and institutions [8]. The feeling of connectedness and its importance for identity are additional social values of land to be considered in terms of what can constitute land grabbing in developed countries [41].

The authors have raised a problem noticeable not only in Poland, but also problematic in other countries worldwide. The authors' intention was to encourage further discussion in this matter. The answers presented in the conclusions to the hypotheses put forward may become the subject of discussion and an incentive for introducing changes in legal regulations.

The strengthening of tools for protecting agricultural land has been observed in Poland in recent years. The rights granted in relation to land under drainless reservoirs aim at additional protection 
of the natural environment and limiting the transformation of, for example, ponds (miniponds) into building land.

Author Contributions: Conceptualization, M.H.; Methodology, A.S. and M.H.; Software, M.H.; Validation, L.H.; Formal analysis, M.H.; A.S.; Investigation, M.H.; Resources, A.S.; K.P.; Data curation, A.S.; Writing-original draft preparation, A.S. and M.H.; Writing—review and editing, M.H.; L.H. K.P. and A.S.; Visualization, A.S.; Funding acquisition, M.H.

Funding: This paper refers to the research conducted under statutory activity, financed by Polish Ministry of Science and Higher Education-Wroclaw University of Environmental and Life Sciences.

Conflicts of Interest: The authors declare no conflict of interest.

\section{References}

1. European Economic and Social Committee. Land-Grabbing-Alarm Bell for Europe and a Threat for Family Farming. The Opinion of the European Economic and Social Committee; European Economic and Social Committee: Brussels, Belgium, 2016. Available online: http:/ / publications.europa.eu/resource/cellar/cdf5739a-4e3f11e6-89bd-01aa75ed71a1.0006.01/DOC_1 (accessed on 10 July 2018).

2. Borras, S.M., Jr.; Franco, J.C.; Gómez, S.; Kay, C.; Spoor, M. Land grabbing in Latin America and the Caribbean. The J. Peasant Stud. 2012, 39, 845-872. [CrossRef]

3. Von Braun, J.; Meinzen-Dick, R. Land Grabbing' by Foreign Investors in Developing Countries: Risks and Opportunities; IFPRI: Washington, DC, USA, 2009.

4. Borras, S.M., Jr.; Hall, R.; Scoones, I.; White, B.; Wolford, W. Towards a better understanding of global land grabbing: An editorial introduction. J. Peasant Stud. 2011, 38, 209-216. [CrossRef]

5. Borras, S.M., Jr.; Franco, J.C. Political Dynamics of Land-Grabbing in Southeast Asia: Understanding Europe's Role; Transnational Institute in the Context of the Just Trade Project: Amsterdam, The Netherlands, 2011; Available online: https: / www.tni.org/files/download/Political\%20Dynamics\%20of\%20Land-grabbing\% 20in\%20Southeast\%20Asia.pdf (accessed on 10 July 2018).

6. Pasour, E.G., Jr. Agricultural Land Protection: Is Government Intervention-Warranted? Cato J. 1982, 2, 739-758.

7. World Bank. Rising Global Interest in Farmland: Can it Yield Sustainable and Equitable Benefits? World Bank: Washington, DC, USA, 2011. Available online: https://siteresources.worldbank.org/DEC/Resources/ Rising-Global-Interest-in-Farmland.pdf (accessed on 10 July 2018).

8. Visser, O.; Spoor, M. Land grabbing in post-Soviet Eurasia: The world's largest agricultural land reserves at stake. J. Peasant Stud. 2011, 38, 299-323. [CrossRef]

9. Schoenberger, L.; Hall, D.; Vandergeest, P. What happened when the land grab came to Southeast Asia? J. Peasant Stud. 2017, 44. [CrossRef]

10. Colchester, M.; Chao, S. Updates on agribusiness and large-scale land acquisitions in Southeast Asia. In Agribusiness Large-scale Land Acquisitions and Human Rights in Southeast Asia, Updates from Indonesia, Thailand, Philippines, Malaysia, Cambodia, Timor-Leste and Burma; Chao, S., Ed.; Forest Peoples Programme: Marsh, UK, 2013; pp. 1-18. Available online: http:/ / www.forestpeoples.org/sites/fpp/files/publication/ 2013/08/lsla-studies.pdf (accessed on 10 July 2018).

11. Manahan, M.A. Is Asia for sale? Trends, issues, and strategies against land grabbing. Kasarinlan Philipp. J. Third World Stud. 2011, 26, 466-481.

12. Sobiecki, R. Interwencjonizm w Rolnictwie: Dlaczego jest Konieczny? Interventionism in Agriculture: Why is It Necessary?], Kwartalnik Nauk o Przedsiębiorstwie [Quarterly of Enterprise Studies], 2015. Available online: http:/ / yadda.icm.edu.pl/yadda/element/bwmeta1.element.ekon-element-000171416895 (accessed on 10 July 2018).

13. Czyżewski, A. Interwencjonizm w polityce krajów wysokorozwiniętych [Interventionism in the policy of high-developed countries]. In Makroekonomiczne Problemy Agrobiznesu w Polsce w Okresie Przedakcesyjnym [Macroeconomic Problems of Agribusiness in Poland in Pre-Accession Period]; Czyżewski, A., Ed.; University of Economics Press: Poznań, Poland, 2003; pp. 9-28.

14. Davis, K.F.; D'Odorico, P.; Rulli, M.C. Land grabbing: A preliminary quantification of economic impacts on rural livelihoods. Popul. Environ. 2014, 36, 180-192. [CrossRef] 
15. Taylor Lovell, S. Multifunctional Urban Agriculture for Sustainable Land Use Planning in the United States. Sustainability 2010, 2, 2499-2522. [CrossRef]

16. Stacherzak, A.; Hełdak, M. Borough Development Dependent on Agricultural, Tourism, and Economy Levels. Sustainability 2019, 11, 415. [CrossRef]

17. Firlej, K.; Żmija, D. The Specificity of Knowledge Management in the Food Industry in Poland. Econ. Manag. 2017, 1, 83-97. [CrossRef]

18. Drabik, D.; Rajčániová, M. Agricultural Land Market In Slovakia Under The New Land Acquisition Law. Rev. Agric. Appl. Econ. 2014, 84-87. [CrossRef]

19. Gugushvili, A. Money can't buy me land: Foreign land ownership regime and public opinion in a transition socjety. Land Use Policy 2016, 142-153. [CrossRef]

20. Constantin, C.; Luminita, C.; Vasile, A.V. Land grabbing: A review of extent and possible consequences in Romania. Land Use Policy 2017, 62, 143-150. [CrossRef]

21. The Act of 24 March 1920 on the Purchase of Real Property by Foreigners (Journal of Laws of 2017, item 2278). Available online: http:/ / prawo.sejm.gov.pl/isap.nsf/DocDetails.xsp?id=WDU19200310178\& type $=3$ (accessed on 10 July 2018).

22. The Act of the 10th February 2017 on the National Support Centre for Agriculture (Journal of Laws of 2017, item 623). Available online: http:/ / prawo.sejm.gov.pl/isap.nsf/DocDetails.xsp?id=WDU20170000623 (accessed on 10 July 2018).

23. Messerli, P.; Heinimann, A.; Giger, M.; Breu, T.; Schönweger, O. From 'land grabbing' to sustainable investments in land: Potential contributions by land change science. Curr. Opin. Environ. Sustain. 2013, 5, 528-534. [CrossRef]

24. Perrings, C. Future challenges. Proc. Natl. Acad. Sci. USA 2007, 104, 15179-15180. [CrossRef]

25. Clark, W.C.; Dickson, N.M. Sustainability science: The emerging research program. Proc. Natl. Acad. Sci. USA 2003, 100, 8059-8061. [CrossRef] [PubMed]

26. Kates, R.W.; Clark, W.C.; Corell, R.; Hall, J.M.; Jaeger, C.C.; Lowe, I.; McCarthy, J.J.; Schellnhuber, H.J.; Bolin, B.; Dickson, N.M. Environment and development: Sustainability science. Science 2001, 292, 641-642. [CrossRef] [PubMed]

27. Seto, K.C.; Reenberg, A.; Boone, C.G.; Fragkias, M.; Haase, D.; Langanke, T.; Marcotullio, P.; Munroe, D.K.; Olah, B.; Simon, D. Urban land teleconnections and sustainability. Proc. Natl. Acad. Sci. USA 2012, 109, 7687-7692. [CrossRef]

28. European Statistical Office. Available online: www.ec.europa.eu/eurostat (accessed on 6 December 2017).

29. Central Statistical Office of Poland (GUS) (2016). Available online: http://www.gus.pl/ (accessed on 6 December 2017).

30. Reports from the Activities of Agricultural Property Agency on the State Treasury Agricultural Property in 2003-2016 r. 2017. In Public Information Bulletin; Agricultural Property Agency: Warszawa, Poland, 2017.

31. The Regulation of the Minister of the Interior Affairs and Administration of 20 June 2012 on Detailed Information and Types of Documents Required to be Presented by a Foreigner Applying for a Permit to Purchase Real Property (Journal of Laws of 2012, item 729). Available online: http:/ / prawo.sejm.gov.pl/ isap.nsf / DocDetails.xsp?id=WDU20120000729 (accessed on 10 July 2018).

32. The Act of April 14, 2016 on Sale Suspension of the State Treasury Agricultural Property and the Change of Some Laws (Journal of Laws of 2016, item 585). Available online: http:/ / prawo.sejm.gov.pl/isap.nsf/ DocDetails.xsp?id=WDU20160000585 (accessed on 10 July 2018).

33. Hełdak, M.; Stacherzak, A.; Kucher, A. Analysis of the changes in transaction prices of agricultural land in Poland. Hradec Econ. Days 2017, 7, 287-295.

34. Hełdak, M. Changes in Transaction Proces of Real Estate and Agricultural Land in Poland in Years 2004-2015. In Proceedings of 17th International Multidisciplinary Scientific GeoConference SGEM 2017, 29 June-5 July 2017; SGEM: Sofia, Bulgaria, 2017; Volume 1777-1784. [CrossRef]

35. The Act of 11 April 2003 on the Formation of Agricultural System ((Journal of Laws of 2018, item 1405). Available online: http:/ / prawo.sejm.gov.pl/isap.nsf/DocDetails.xsp?id=WDU20030640592 (accessed on 6 December 2017). 
36. Maśniak, J. Interwencjonizm na rynku ziemi rolniczej z perspektywy austriackiej szkoły ekonomii [Interventionism on the market of agricultural land from the perspective of Austrian Scholl of Economics]. In Scientific Yearbook; Association of Agriculture and Agribusiness Economists: Warszawa, Poland, 2014; Volume 17.

37. Supreme Court of Poland. The Decision of Supreme Court Dated 25 December 2008, II CNP 70/08, LEX No. 484703; Supreme Court of Poland: Warszawa, Poland, 2008.

38. Gajewska, E.; Iwaszkiewicz, P. Gospodarstwa rodzinne w systemie obrotu nieruchomościami rolnymi w Polsce [Family Farms in the System of Agricultural Property Trading in Poland]. Przeglad Prawa Rolnego 2015, 159-178. [CrossRef]

39. The Act of 20th July 2017 Water Law (Journal of Laws of 2017, item 1566). Available online: http:/ / prawo. sejm.gov.pl/isap.nsf/DocDetails.xsp?id=WDU20170001566 (accessed on 10 July 2018).

40. Bunkus, R.; Theesfeld, I. Land Grabbing in Europe? Socio-Cultural Externalities of Large-Scale Land Acquisitions in East Germany. Land 2018, 7, 98. [CrossRef]

41. Gunnoe, A. The Political Economy of Institutional Landownership: Neorentier Society and the Financialization of Land. Rural Sociol. 2014, 79, 478-504. [CrossRef]

42. Mamonova, N. Resistance or adaption? Ukrainian pesants' response to large-scale land aquisitions. J. Peasant Stud. 2015, 42, 607-634. [CrossRef]

43. Van der Ploeg, J.D.; Franco, J.C.; Borras, S.M., Jr. Land concentration and land grabbing in Europe: A preliminary analysis. Can. J. Dev. Stud. 2015, 36, 147-162. [CrossRef]

(C) 2019 by the authors. Licensee MDPI, Basel, Switzerland. This article is an open access article distributed under the terms and conditions of the Creative Commons Attribution (CC BY) license (http:/ / creativecommons.org/licenses/by/4.0/). 